BIOINGENIERÍA

INGENIERÍA MECÁNICA

\title{
Determinación de las variables topográficas más representativas en Sockets para amputados transfemorales fabricados nacionalmente
}

BIOENGINEERING

MECHANIC ENGINEERING

\section{Determining the most representative topographic variables in locally manufactured sockets for patients with transfemoral amputation}

\author{
Vanessa Restrepo*§, Junes A Villarraga*, Juan José Pavón** \\ *Departamento de Ingeniería Mecánica, Facultad de Ingeniería, Universidad de Antioquia, \\ Medellín-Colombia. \\ **Departamento de Bioingeniería, Facultad de Ingeniería, Universidad de Antioquia, Medellín- \\ Colombia. \\ §vanessa.restrepop@udea.edu.co, junes@udea.edu.co,jjpavon@udea.edu.co.
}

(Recibido: 12 de Diciembre de 2012 - Aceptado: 13 de Abril de 2013)

\begin{abstract}
Resumen:
El nivel de confort de un paciente amputado transfemoral está ligado al coeficiente de fricción (CF) en la interfaz SocketMuñón, se ha demostrado experimentalmente que las características superficiales del elemento que entra en contacto con la piel influyen en el CF. Partiendo del modelo en yeso del muñón de un paciente amputado transfemoral se fabrican seis sockets en empresas de diferentes ciudades a nivel nacional (Bogotá, Medellín y Cali), con el fin de determinar los cambios a nivel topográfico dependiendo del proceso y fabricación, se establece el procedimiento general para la fabricación de un socket se identifican las zonas con mayores esfuerzos en el muñón partiendo de modelos por elementos finitos y se extraen probetas de los sockets. Con un rugosimetro, se caracteriza la superficie de las muestras teniendo como criterios los parámetros tribológicos Ra, Rq y Rpc. Se concluye que debido a lo altamente artesanal del proceso de fabricación, las características tribológicas varían enormemente de un socket a otro, lo cual plantea la posibilidad de realizar en el futuro protocolos de fabricación que incluyan el texturizado superficial en determinadas zonas de los sockets y de esta forma variar los coeficientes de fricción y mejorar la precepción de confort de los pacientes.
\end{abstract}

Palabras Clave: Amputado Transfemoral, Caracterización superficial, Parámetros tribológicos, Rugosidad.

\begin{abstract}
.
The degree of comfort of a patient with transfemoral amputation is directly related to the Coefficient of Friction (COF) at the Socket-Stump interface. It has been experimentally proven that surface characteristics of the element contacting the skin have an impact on the COF. Based on the gypsum model of a patient with transfemoral amputation, six sockets are manufactured in companies from several cities of the country (Bogotá, Medellín, and Cali) with the purpose of determining the topographic changes based on the manufacture process. General procedure to manufacture the socket is established, the areas exercising the biggest stress on the stump are identified based on finite-element models, and samples are taken from sockets. Through a roughness tester, surface of samples is characterized having Ra, Rq, and Rpc as tribological parameters. It is concluded that due to the highly artisanal degree of the manufacture process tribological characteristics significantly vary from one socket to another, which allows having a possibility to perform, in the future, manufacture protocols to include surface texture on specific areas of sockets in order to modify coefficients of friction and increase patients' comfort.
\end{abstract}

Keywords: transfemoral amputation; surface characterization; tribological parameters; roughness. 


\section{Introduction}

A person with transfemoral amputation is an individual who has lost one or both lower extremities at the level of femur or above the knee. A prosthesis for a transfemoral amputee consists of several basic elements: a prosthetic foot, a prosthetic knee, rods or joining elements, and a socket; this element of a prosthesis is in direct contact with the patient; for this reason, its design is a fundamental factor for the patient's perception of comfort and functionality.

It has been proven that shear strength and excessive pressure on the socket-stump interface are the principal causes of damage to patient's soft tissues, resulting in circulation disorders, pressure ulcers, infection, and injuries (Bennett, et al., 2009; Li, et al., 2011; Zhang, et al., 1996). Sockets are manufactured with different materials depending on the type of amputation; they can be manufactured with resin, carbon fiber, and polypropylene, but the ones manufactured with polypropylene are the most commonly used and the subject matter of this research.

Polypropylene-skin interaction has been studies before (Portnoy et al., 2009; Ramírez, 2011; Restrepo, 2012; Vélez \& Piedrahita, 2011), but it should be noted that research works conducted are not entirely updated and have been executed with technology not accessible today. Likewise, the coefficient of friction between polypropylene and skin is slightly impacted by both skin moisturizing conditions and surface roughness of polypropylene (Hendriks \& Franklin, 2010).

Prosthesis manufacture in Colombia is an especially artisanal process in which the manufacturer's knowledge and experience is a vital factor. Socket manufacture process can be standardized in several basic steps which do not exhibit significant changes among prosthesis manufacturers. Since the socket shape is unique for each patient, a customized work should be done. For this reason, uniformity of final product cannot be achieved and problems of some amputees are difficult to generalize since prosthesis manufacture basically lies on the prosthesis shape.
Although there are not accurate calculations, “Asociación Colombiana de Medicina Física y Rehabilitación" has estimated that amputation incidence in the country is found in 200 to 300 people for each 100,000 inhabitants. This figure is calculated bearing in mind that about $10 \%$ of population exhibits certain kind of disability and 5 to $10 \%$ of disabled people are actually amputees. $85 \%$ of amputations are caused by peripheral vascular diseases, with or without diabetes, 10 to $12 \%$ of them are due to a trauma, and 3 to $5 \%$ is caused by other factors (WHO Disability and Rehabilitation, s. f.).

In Colombia (when compared to other countries), the amputation incidence of lower limbs, caused by the armed conflict, is even higher. Between 1990 and November 2011 a total of 9,584 victims of APM (Anti-Personnel Mines) and UO (Unexploded Ordnance) were reported. Out of these, $79 \%(7,575)$ were injured and $21 \%(2,009)$ died (Situación Nacional de Víctimas de Minas Antipersonal, s. f.). These figures should be added with car accidents, where events involving motorcyclists are about 450 per day, resulting in 13 deaths and 100 seriously injured individuals (Fondo de Prevención Vial, s. f.), and most part of these injured people require amputation.

This study was conducted in three of the most important cities of the country (Medellín, Bogotá, and Cali) with the purpose of establishing several socket manufacture processes for transfemoral amputees. After a finite-element study, areas of interest where the highest stress values on the amputee's stump when using the socket are specifically observed. Sockets manufactured to analyze different tribological parameters in areas of interest and to identify the interaction between the manufacture process and measured values are treated over this basis. In the past, it has been established that the coefficient of friction between polypropylene and skin is dependent on the surface roughness.

\section{Methodology.}

\subsection{Socket manufacture.}

Socket manufacture process for transfemoral amputees in Colombia is a basically artisanal 


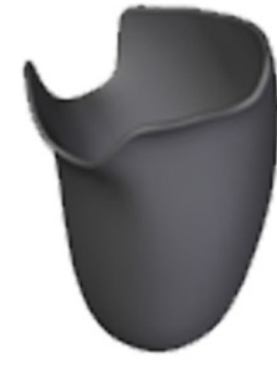

a

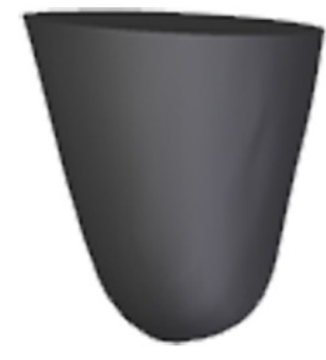

b

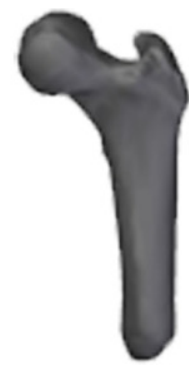

C

Figure 1. CAD models of numerical simulation elements; a) socket; b) soft tissues; and c) femur.

process; design and manufacture are more based on the manufacturer's expertise than on a standardized method. For this study, six sockets at six companies located in cities such as Bogotá, Medellín, and Cali were manufactured.

The manufacture process is almost the same in all the companies and involves the following steps:

1) Taking model measurements; 2) measuring and cutting of sheets; 3) model preparation; 4) heating of polypropylene sheet; 5) coating of model with the sheet; 6) cutting of excess material; 7) socket cooling; 8) socket extraction; 9) socket finish.

The only significant differences were seen at companies 1 from Medellin and Bogotá, where a double coating during model preparation was applied and socket cooling was conducted with water in order to decrease waiting time before extracting the socket. Additionally, at company 2 from Cali, talc is poured on the model before adding molten polypropylene as a way to make socket extraction easier.

\subsection{Numerical model}

In order to get a real idea of the areas where measurement of tribological parameters over sockets under study should be made, a dynamic simulation of the stump-socket-femur system was conducted (Figure 1) based on the finite-element method; in this model, the most critical conditions during the human walking process were noticed (specifically during the supporting stage); for simplicity purposes, the loads generated on the sagittal plane were taken into account.

Properties used for socket and femur are homogeneous and isotropic (Table 1), and densities were $800 \mathrm{Kg} / \mathrm{m}^{3}$ (Lee, Zhang, Jia, \& Cheung, 2004; Ming Zhang \& Mak, 1996) and $2000 \mathrm{Kg} / \mathrm{m}^{3}$ (Duchemin et al., 2008), respectively; in relation to soft tissues, a multilayer model was used for distinguish among muscle, adipose tissue, and skin, and the Mooney-Rivlin (Eq. 1) hyperelastic model was used with a density of $1000 \mathrm{Kg} / \mathrm{m}^{3}$ (Zheng, Mak, \& Leung, 2001).

$w=c_{10}\left(I_{1}-3\right)+c_{11}\left(I_{2}-3\right)\left(I_{2}-3\right)-\frac{1}{D_{1}}(J-1)^{2}(1)$

Where $I_{l}, I_{2}, J$ are invariant stresses of the main tensor, and $c_{10}, c_{11}, D_{1}$ (Portnoy et al., 2009) are experimentally determined constants.

With results obtained areas in which there is concentration on stress and pressure values

Tabla 1. Propiedades mecánicas de los materiales

\begin{tabular}{|c|c|c|c|c|c|}
\hline Material & $\begin{array}{c}\text { Young'smodulus } \\
\text { (GPa) }\end{array}$ & Poisson & $\begin{array}{r}C_{10} \\
(\mathrm{kPa}) \\
\end{array}$ & $\begin{array}{c}C_{11} \\
(\mathrm{kPa} a) \\
\end{array}$ & $D_{1}\left(M P a^{-1}\right)$ \\
\hline Polipropileno* & 1.5 & 0.3 & NA & NA & NA \\
\hline Cortical Bone** & 15 & 0.3 & NA & NA & NA \\
\hline Skin*** & NA & NA & 9.400 & 82 & 0 \\
\hline Fat*** & NA & NA & 0.143 & 0 & 70.2 \\
\hline Muscle*** & NA & NA & 8.075 & 0 & 1.243 \\
\hline
\end{tabular}

*(Lee, Zhang, Jia, \& Cheung, 2004; Ming Zhang \& Mak, 1996), **(Duchemin et al., 2008), ***(Portnoy et al., 2009) 
(Figure 2) are identified for the case of a coefficient of friction of 0.5 between socket and skin.
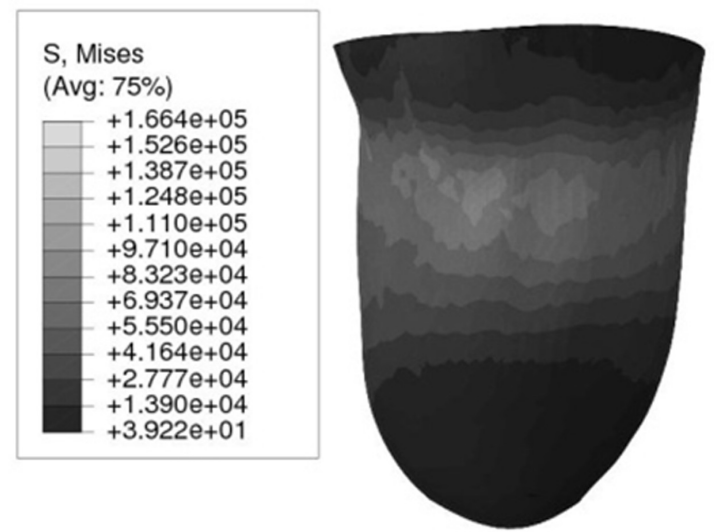

a
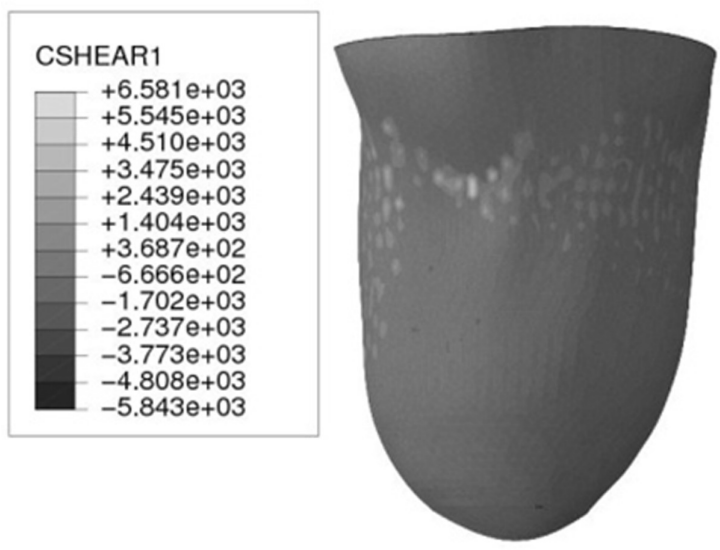

b

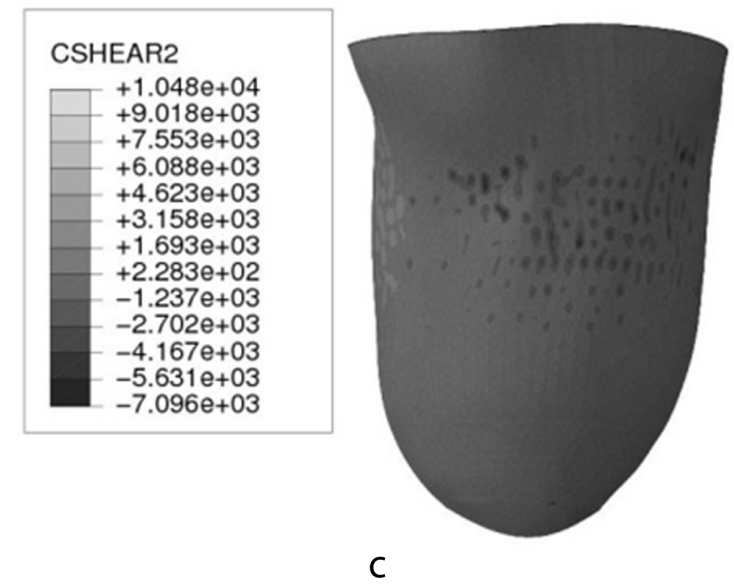

Figure 2. Distribution of stresses and pressures on the stump of a patient with transfemoral amputation. A) Von Mises, b) Shear 1, c) Shear 2.

\subsection{Preparation of Manufacture of samples}

After analyzing the results obtained, twelve areas (Figure 3) are proposed for preparing the samples on which tribological measurements of parameters $\mathrm{Ra}, \mathrm{Rq}$, and $\mathrm{Rpc}$ will be made. A measurement of $2 \mathrm{~cm} \times 2 \mathrm{~cm}$ was estimated for each sample with the purpose of having sufficient area for reaching representative data of the area and assuring a good attachment to the roughness tester.

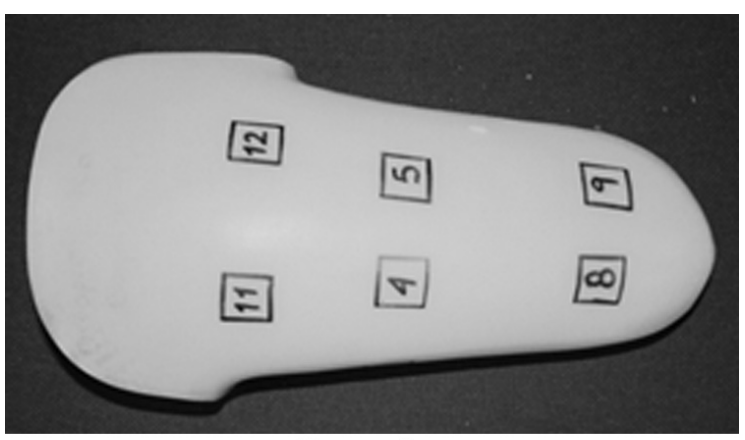

\section{Posterior}

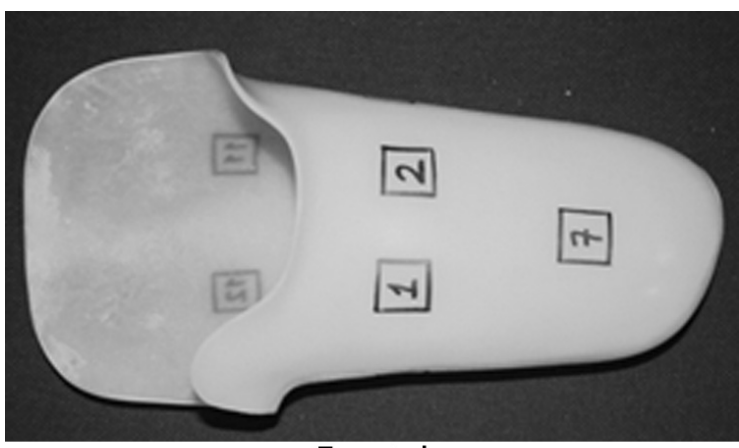

Frontal

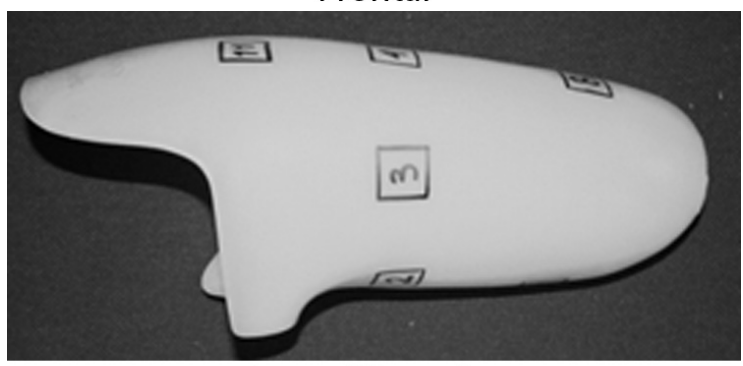

Lateral Derecha

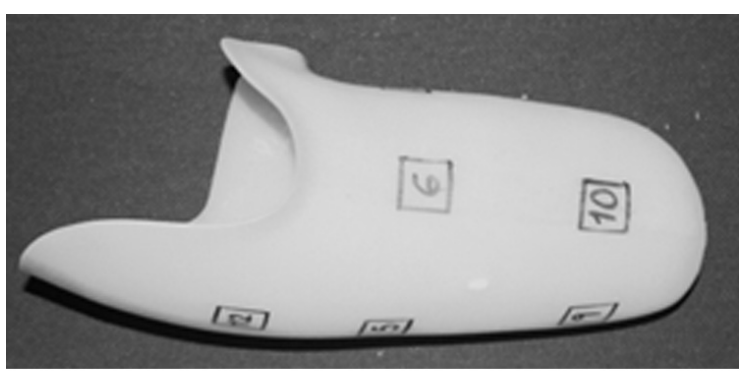

Lateral Izquierdo

Figure 3: Location of socket samples.

\subsection{Measurement of tribological parameters}

A Mitutoyo SV - 3000M roughness tester was employed. Longitudinal and transversal 
measurements were taken to each sample. Primary profiles and values of $\mathrm{Ra}, \mathrm{Rq}$, and Rpc features were obtained. These values were tabulated and plotted on graph for future analysis.

\section{Results and discussion}

Behavior of tribological parameters $\mathrm{Ra}$ and $\mathrm{Rq}$ (longitudinal and transversal directions) of the six companies visited in Medellin, Bogotá, and Cali is shown in Figures 4, 5, and 6. These figures show that longitudinal direction values exceed those of transversal direction.

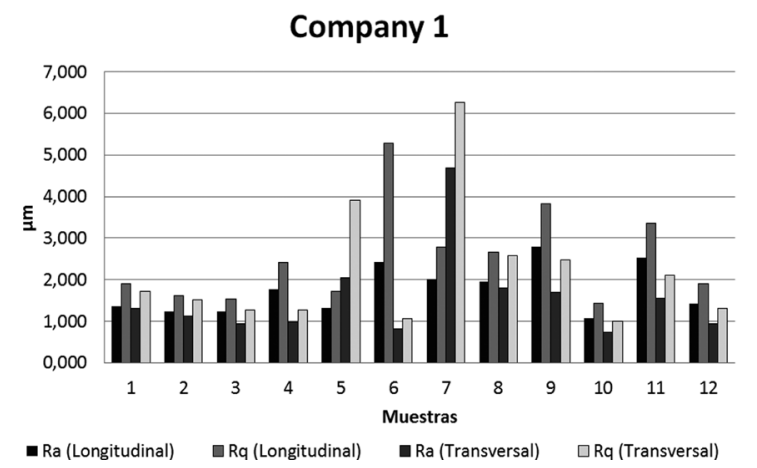

A general trend is kept exhibiting that samples 6 and 7 show higher values that $\mathrm{Ra}$ and $\mathrm{Rq}$ in the different companies. Sample 6 is located on the left side area and Sample 7 on the lower front side of the socket (Figure 3).

There is not an association between the way socket is manufactured and the measurements taken; this is mainly due to the procedure in itself, since it is a highly artisanal procedure and is dependent on the prosthesis manufacturer's experience and knowledge (Ramírez, 2011).

Figure 4: Companies in Medellin City.
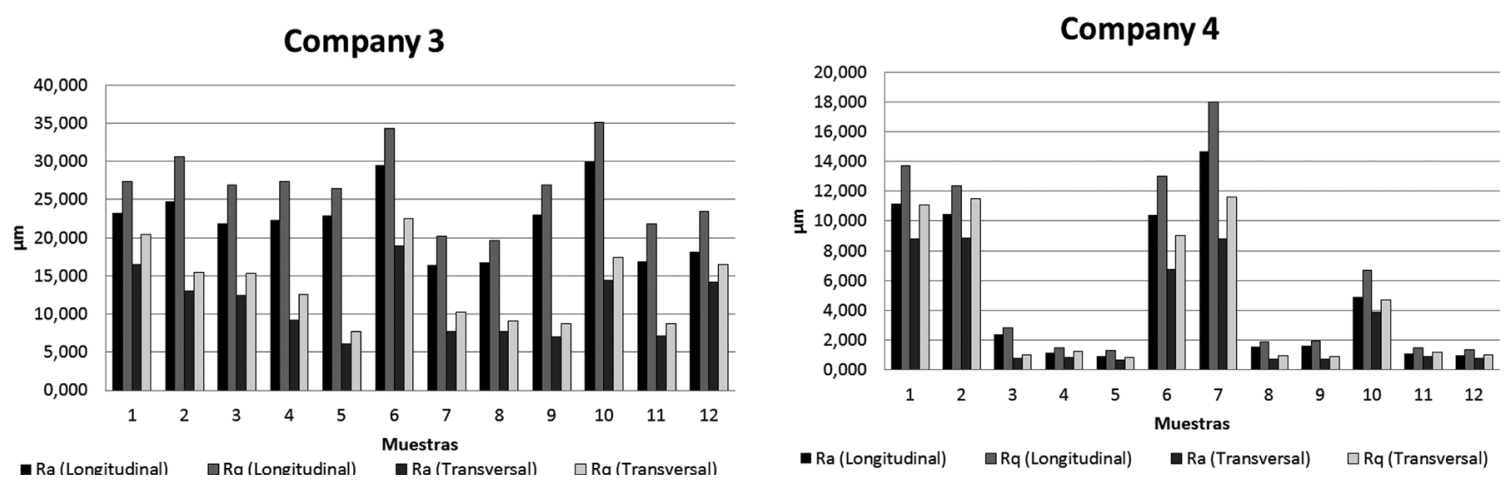

Figure 5: Companies in Bogotá City.
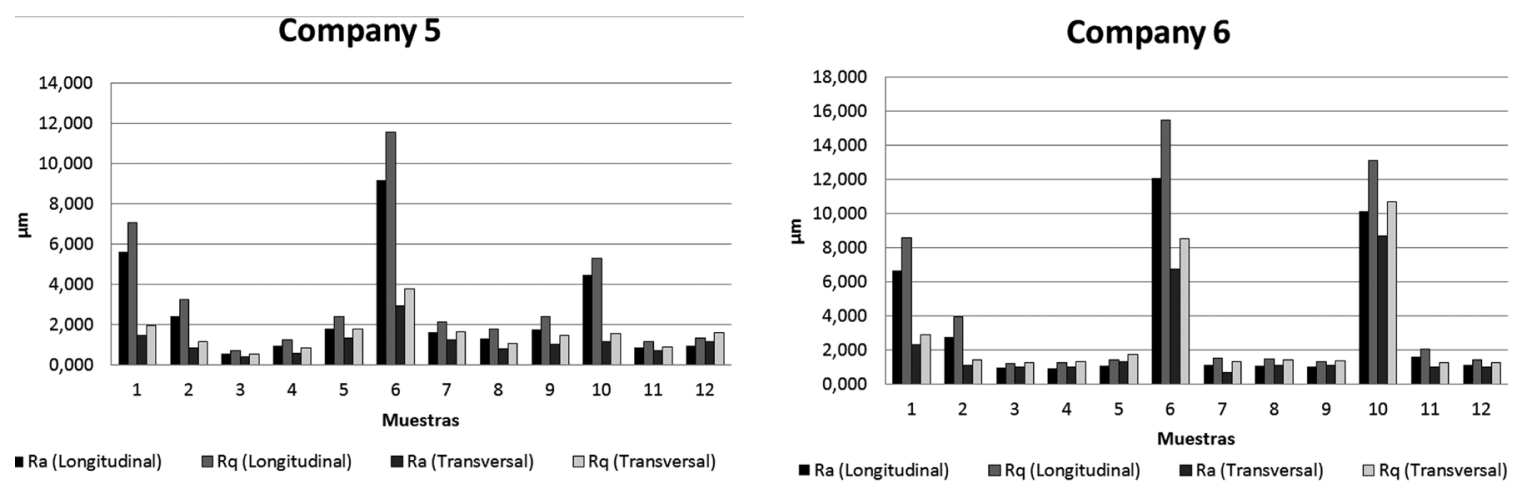

Figure 6: Companies in Cali City. 
Company 1 in Bogotá City exhibits the highest values of the tribological parameters of the study conducted since its manufacture methods significantly differ from the other ones. This company employs double nylon socks for socket manufacture.

Peak concentration by unit of length measured becomes higher in the transversal direction due to the fiber orientation of the nylon socks used during the socket manufacture process. This peak distribution can affect interaction between socket and stump when COF resulting between the two surfaces is varied, as inferred from prior works (Restrepo, 2012) in which it is clear that COF may vary when changing polypropylene surface topography; this is supported by research of Hendriks \& Franklin, 2010. For this reason, it should be established whether there is a significant difference in the coefficient of friction generated on each of these directions since this has a holding effect and results in abrasion and other kind of skin injuries.

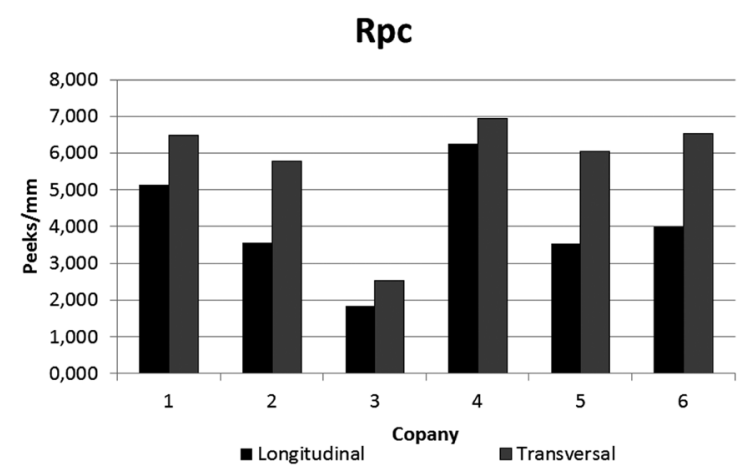

Figure 7. Peaks density by unit of length.

\section{Conclusions}

Manufacture processes where two nylon socks during the model preparation stage were used, Ra and $\mathrm{Rq}$ values were higher than the other ones.

At a longitudinal level, roughness values are higher than those of the transversal direction. This is caused by the pattern left by the socks during the thermoforming process.

Since manufacture is an extremely artisanal process and is dependent on several factors such as the prosthesis manufacturers' experience and the socket cooling method, there is not a general trend on surface topography of the areas where measurements were made, even in sockets manufactured within the same company.

It is important to understand how manufacture process for amputees' sockets may affect surface roughness since this element (being the only element contacting the patient) is the most important factor when trying to make designs to improve patients' comfort perception.

It should be determined if there is any difference among measurements of the coefficient of friction in the different directions, as an effect of peak concentration by unit of measure.

Since surface texture (and therefore tribological parameters) affects stress distribution on soft tissues, these results give rise to the execution of future studies intended to control such parameters on the socket surface from manufacture methods by using additional texturizing processes which can be performed with a future chemical or mechanical material removal process.

\section{Acknowledgment}

The authors want to thank CIA ("Centro de Investigaciones Ambientales y de Ingeniería") for its financial support for conducting this project.

\section{References}

Bennett, L., Kavner, D., Lee, B. K., \& Trainor, F. A. (1979). Shear vs pressure as causative factors in skin blood flow occlusion. Archives of physical medicine and rehabilitation, 60(7), 309-314.

Duchemin, L., Bousson, V., Raossanaly, C., Bergot, C., Laredo, J. D., Skalli, W., \& Mitton, D. (2008). Prediction of mechanical properties of cortical bone by quantitative computed tomography. Medical Engineering \& Physics, 30(3), 321-328. doi:10.1016/j. medengphy.2007.04.008

Fondo de Prevención Vial. (s. f.). Recuperado septiembre $25,(2011)$ a partir de http://www. fonprevial.org.co/index.php?option $=$ com_rubb 
erdoc $\&$ view $=$ category $\&$ id $=107 \% 3$ Aestadistica $\mathrm{s} \&$ Itemid $=81$

Hendriks, C., \& Franklin, S. (2010). Influence of Surface Roughness, Material and Climate Conditions on the Friction of Human Skin. Tribology Letters, 37(2), 361-373. doi:10.1007/ s11249-009-9530-7

Lee, W. C. C., Zhang, M., Jia, X., \& Cheung, J. T. M. (2004). Finite element modeling of the contact interface between trans-tibial residual limb and prosthetic socket. Medical engineering \& physics, 26(8), 655-662.

Meulenbelt, H. E., Geertzen, J. H., Jonkman, M. F., \& Dijkstra, P. U. (2009). Determinants of skin problems of the stump in lower-limb amputees. Archives of Physical Medicine and Rehabilitation, 90(1), 74-81. doi:10.1016/j. apmr.2008.07.015

Ming Zhang, \& Mak, A. F. . (1996). A finite element analysis of the load transfer between an above-knee residual limb and its prosthetic socket-roles of interface friction and distalend boundary conditions. IEEE Transactions on Rehabilitation Engineering, 4(4), 337-346. doi:10.1109/86.547935

Portnoy, S., Siev-Ner, I., Yizhar, Z., Kristal, A., Shabshin, N., \& Gefen, A. (2009). Surgical and morphological factors that affect internal mechanical loads in soft tissues of the transtibial residuum. Annals of Biomedical Engineering, 37(12), 2583-2605. doi:10.1007/s10439-0099801-3

Ramírez, J. (2011). Nivel de Confort y Distribución de Esfuerzos en la Interfaz Socket
- Muñón en Amputados Transfemorales (Tesis Doctoral). Universidad Nacional de Colombia, Medellín, Colombia.

Restrepo, V. (2012). Optimización Superficial de un Socket para Amputado Transfemoral que Disminuya los Esfuerzos Variando el Coeficiente de Fricción (Tesis de Pregrado). Universidad de Antioquia, Mdellín.

Situación Nacional de Víctimas de Minas Antipersonal. (s. f.). Recuperado enero 16, 2012, a partir de http://www.accioncontraminas. gov.co/Paginas/victimas.aspx

Vélez, J., \& Piedrahita, M. (2011). Análisis de la influencia del porcentaje del miembro residual en la distribución de esfuerzos y presiones en la interfaz socket-muñón (Tesis de pregrado). Universidad de Antioquia, Medellín, Colombia. W. Li, X. D. Liu, Z. B. Cai, J. Zheng, \& Z. R. Zhou. (2011). Effect of prosthetic socks on the frictional properties of residual limb skin. Wear, 271(11-12), 2804-2811.

WHO | Disability and rehabilitation: WHO action plan 2006-2011. (s. f.).WHO. Recuperado abril 16, 2012, a partir de http://www.who.int/disabilities/ publications/action_plan/en/index.html

Zhang, M., Turner-Smith, A. R., Roberts, V. C., \& Tanner, A. (1996). Frictional action at lower limb/prosthetic socket interface. Medical Engineering \& Physics, 18(3), 207-214.

Zheng, Y. P., Mak, A. F., \& Leung, A. K. (2001). State-of-the-art methods for geometric and biomechanical assessments of residual limbs: a review. Journal of Rehabilitation Research and Development, 38(5), 487-504. 